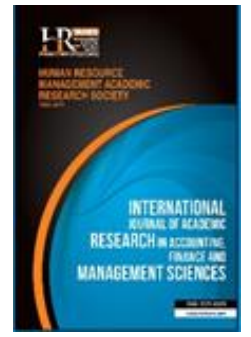

International Journal of Academic Research in Accounting, Finance and Management Sciences

Vol. 10, No.1, January 2020, pp. 189-196

E-ISSN: 2225-8329, P-ISSN: 2308-0337

(c) 2020 HRMARS

www.hrmars.com

To cite this article: Seiyaibo, C. M. (2020). Has the Adoption of International Public Sector Accounting Standards (IPSAS) Reduced Corruption in the Nigerian Public Sector, International Journal of Academic Research in Accounting, Finance and Management Sciences 10 (1): 189-196.

\title{
Has the Adoption of International Public Sector Accounting Standards (IPSAS) Reduced Corruption in the Nigerian Public Sector?
}

\section{Carl Madawa Seiyaibo}

Accountancy Department of Nnamdi Azikiwe University, Awka, Nigeria, E-mail: carlseyaibo@yahoo.com

\begin{abstract}
This study empirically examines the adoption of International Public Sector Accounting Standards (IPSAS) and its impact on reducing Corruption in the Nigerian Public Sector. Utilizing survey research design, primary data were obtained by means of structured questionnaires administered on three hundred (300) respondents comprising accounting practitioners from the public sector and academia in Bayelsa State Nigeria, Data analysis was conducted using Chi-square statistical tools and SPSS ("Statistical Product and Service Solutions") version 22.0, The study revealed that accrual based IPSAS provides more information to forensic accountants in executing their job effectively. Equally, the findings suggest that report generated through IPSAS adoption helps forensic accountants in building sound internal control mechanism in the public sector. Thus, it is recommended that government at all tiers should adopt IPSAS given its numerous benefits despite minor implementation challenges which can be rectified by relevant regulatory agencies.

Key words IPSAS, Corruption, Forensic Accounting, Disclosure, Financial Reporting Quality

Received: 17 Feb 2020 (C) The Authors 2020

Revised: 20 Mar $2020 \quad$ Published by Human Resource Management Academic Research Society (www.hrmars.com)

Accepted: 28 Mar 2020 This article is published under the Creative Commons Attribution (CC BY 4.0) license. Anyone may Published Online: $06 \mathrm{Apr} 2020$ reproduce, distribute, translate and create derivative works of this article (for both commercial and non-commercial purposes), subject to full attribution to the original publication and authors. The full terms of this license may be seen at: http://creativecommons.org/licences/by/4.0/legalcode
\end{abstract}

\section{Introduction}

The malaise of Corruption has been universally recognized as an epidemic cancerously devastating major regions of the globe, however, its menace is felt more in developing countries as it negatively impacts on the socio-economic and political developments. Nigeria since independence from colonial rule has been bedevilled with this hydra -headed monster impeding the realization of her socio-economic expansion (Adedeji et al., 2018). According to Nageri et al. (2013), corruption is a key factor militating against rapid growth and development of the Nigerian economy, despite its abundant natural and human resources, Studies revealed that the Nigerian private sector in collusion with ministries, departments and agencies of government are complicit in the preponderance of corrupt practices (Okeke, 2012).

In a bid to curtail the corruption menace, government on its part have employed various measures comprising the establishment of Independent Corruption and other Related Practices Commission (ICPC), adoption of International Public Sector Accounting Standard (IPSAS), Treasury Single Account (TSA), the ongoing sanitization in the Nigeria National Petroleum Co-operation (NNPC), public services reform, Economic and Financial Crime Commission (EFCC), Financial Intelligent Unit (FIU), Public Procurement Act, Fiscal Responsibility Act, Bank Verification Number (BVN) and policy of whistle blower policy.

Suffice it to note that since 2017 Nigeria has consistently featured in the bottom list of rankings in the Corruption Perception Index (CPI) as released by Transparency International (TI), according to the 2018 report, Nigeria ranked 144 out of 180 countries surveyed, indicating that the country dropped two steps 
below the 2017 rankings. Nigeria also scored 27 out of 100 points in the $2018 \mathrm{CPI}$, maintaining the same score as in the $2017 \mathrm{CPI}$, the same as it did in 2018. The score is below the global average of 43 . According to the 2019 CPI, two-thirds, which are 120 countries, scored below 50. Countries within Sub-Saharan Africa also have the lowest average with 32 over 100 points. In 2014 Nigeria ranked 136, indicating high prevalence of corruption, while, Somalia was at the base of the corruption ranking of 174 by (Nageri et al., 2013).

The essence of public sector financial accounting is to demonstrate the reasonableness of how transactions are made in conformity with laid down rules. Basically, it assists in providing documentary evidence on stewardship and accountability reporting concerning the utilization of government critical resources while providing reliable, adequate and material information that assists in the prudent management and control of government activities and transactions. Hence the adoption of International Public Sector Accounting Standard (IPSAS) will usher in qualitative and reliable financial statement that will discourage discretionary application while simultaneously promoting increased disclosure of financial information that will support accountability, transparency, comparability, and integrity, however, the absence of relevant disclosure system reported in financial statements encourages corruption and stymies the efforts of government agencies in the fight to mitigate its untoward effects.

In the light of the foregoing this study aims at empirically appraising the impact of International Public Sector Accounting Standards Adoption (IPSAS) adoption on public sector accountability in order to establish if it has significantly reduced Corruption in the Nigerian Public Sector. To achieve this objective, this paper will attempt to $X$-ray the following research questions:

(i) How true is the assertion that accrual based IPSAS provide more accounting information to stakeholders than cash basis accounting system in decision making?

(ii) To what extent has poor financial reporting and disclosure requirement increased the incidences of corruption in the Nigerian public sector?

(iii) How true is the assertion that accrual based IPSAS provides more information to forensic accounting experts in executing their job?

(iv)To what extent will reports generated by forensic accountants assist in building sound internal control structure in the public sector through IPSAS adoption?

\section{Literature review}

\subsection{Concept of Corruption}

Corruption in the public sector can be aptly described as a scenario where public office holders divert, misappropriate public fund entrusted to them for their personal use. It is also favouritism shown by public officials to relatives or close allies. Akindele (2005) define corruption as a behaviour that contravenes the norms, values and practices governing an individual in a position of authority. Osunyinkanmi (2009) views corruption as synonymous with economic and other vices of misconduct.

Klitgaard (1998) opines that corruption encompasses a wide array of illicit behaviours, favouritism, graft, pilferage, influence-peddling, kick-back, falsification, nepotism and other immoral indiscipline's he further asserted that corruption is an embodiment of monopolised power and absence of accountability with discretional application of policies and decision he mathematically demonstrated this anomie with an equation: $C=M+D-A$, where $C=$ corruption, $M=$ monopoly, $D=$ discretion and $A=$ accountability. Moreso, the United Nations Development Programme (UNDP) modified Klitgaard's formula by introducing integrity and transparency.

Hence, formulated a new formula expressed as follows $C=(M+D)-(A+I+T)$, where $C=$ corruption, $M=$ monopoly, $D=$ discretion, $A=$ accountability, $I=$ integrity and $T=$ transparency. Hence it can be deduced that the absence of accountability, integrity and transparency (AIT) creates weak governance and the summation of discretion and monopolised power results to corruption (Balboa \& Medalla, 2006). However, Corruption control requires a multifaceted strategy in the form of establishment of regulations, code of conducts, enlightenment campaigns, value re-orientation and whistle blower protection mechanism (Adedeji et al., 2018). Equally, Khan (2006) noted that corruption control architecture established by Management changes the compliance behaviour of corruption perpetrator from negative to positive. 


\subsection{Role of Law Enforcement Agencies in Combating Corruption}

Hitherto, the police and some allied sister agencies were solely responsible for the fight against corruption in Nigeria which yielded little results in the battle against corruption, hence, different anticorruption agencies were created to effectively implement and reinforce policies and programmes aimed at corruption reduction and control in order to bring economic and financial crimes to the barest minimum in this wise, the Independent Corrupt Practices Commission (ICPC) was established on the $29^{\text {th }}$ of September 2000 by former President Olusegun Obasanjo also in the same vein, the Economic and Financial Crimes Commission was established in 2003.

To overcome corruption, Nigerians, are enjoined to imbibe attitudinal qualities of transparency, integrity, and accountability in all their private and public dealings. Fabayo et al. (2011), in their study analyzed the consequences of corruption activities on investment in Nigeria by employing OLS technique utilizing yearly corruption perception index (CPI) for the period 1996 and 2010. Outcome of the study reveals high level of corruption, which have negatively impacted investment and economic development in Nigeria. They noted that the key drivers of corruption included; weak government institutions, poor pay and incentives, lack of transparency in public service, weak and politicized anti-corruption agencies, ineffective political processes and the acceptance of corrupt public officers by the citizenry.

\subsection{International Public Sector Accounting Standards Adoption (IPSAS)}

IPSAS refers to the government's version of the International Financial Reporting Standards (IFRS), established by the International Accounting Standards Board (IASB). IPSAS are the professional version of laws and standards on government accounting and financial reporting. They were developed by experts appointed by a global federation of the accounting professional bodies in over 100 countries. IPSAS address the rationale of financial measurement and financial reporting to the public. However, the International Public Sector Accounting Standard Board (IPSASB) has no enforcement right in the implementation of the standards in Nigeria. It however encourages countries to adopt and harmonise its locally established standards with the IPSAS. In Nigeria, the Financial Reporting Council of Nigeria (FRCN) is mandated to enforce the implementation of the established standards. The Federation Account Allocation Committee (FAAC) came up with different modalities to have it implemented in the three tiers of government.

To have a better footing in the implementation of IPSAS, FAAC recommended uniform national chart of accounting and user manual as well as uniform accounting policies. It also provided uniform budget template of IPSAS cash basis alignment. The operating arms of the FRC that is in charge of the Public Sector is empowered to develop accounting and financial reporting standards for the public sector, by taking into account significant areas of accounting and financial reporting that could be improved through the standard-setting process, furthermore it has the responsibility to encourage the overall setting and implementation of such values by developers and employers of financial statements in the public sector; also to ensure that the Public Sector compared with the accounting ethics recognized or reviewed by the Directorate, the council is duty bound to evaluate from period to period the accounting values advanced in conformity with the predominant social, economic and political environment.

Accrual based IPSAS has been widely researched by experts in the public sector in order to identify the relevant environmental variables that impact on its application (Luder, 1992, 1994; Pallot, 1996, Ryan, 1998). Chile was the first state that introduced accrual basis of accounting for the public sector in early 70s, followed by New Zealand in 1990.New Zealand had a comprehensive change; other countries have also made gradual changes. The USA Generally Accepted Accounting Principles (accrual basis of accounting) have its adoption only in some states (Carpenter \& Feroz, 2001). In USA and Australia, accrual accounting occurred in 1997 while; Canada took over the system in 2001-2002. But countries like Norway, Lithuania and Austria used full cash basis system. The applied cash basis is used for both the budget and the accounts of the core ministries, but for some items viewed critical are supplemented with accrual basis data. International Public Sector Accounting Standards (IPSAS) is for the public sector entities and does not cover government business enterprise (GBE). IPSAS urged GBE to apply International Financial Reporting Standards (IFRS) to report on its business activities. International Public Sector Accounting Standards Board (IPSASB) is an independents board founded by the international Federation of Accountants (IFAC), with the primary objective to develop and publish IPSAS. 


\subsection{Benefits and challenges of IPSAS Adoption in Nigeria}

ljeoma \& Oghoghomeh (2014) suggested that IPSAS adoption will help provide more reasonable information of high quality that can help decision makers to make quality decision. Moreover, IPSAS application improves comparability of financial information across entities. While promoting Accountability; Transparency; Improved Credibility/Integrity; Political Leverage, Comparability, Greater Disclosures of Information and Increased control of public agencies. Besides the benefits accruable from the adoption of IPSAS, it has faced some criticism. IPSAS standards are issued on the basis of IAS/IFRS and applied to enterprises without preparing a general framework for public sector entities that differ in many crucial aspects from for-profit organizations (Oulasvirta, 2008).

For example, in government sector, control of budget implementation matters and accountability concerns not only financial performance, but also operative and non-financial performance result (Christiaens \& Skaerbaek, 2007). Barton (2005) averred that in the adoption of IPSAS no consideration was made on the relationship between governments and the business sector and its operational environment and roles were not critically made. Accounting standards are expected to be tailored to suit the specific information needs of each sector for the accounting systems to provide relevant information as per country peculiarities.

In the same vein, Roje et al. (2012) posited that IPSAS adoption is beneficial and becoming more and more relevant as many countries are moving towards applying full accrual accounting in its financial reporting. Nongo (2014), opined that usage of IPSAS reporting system in the public sector have the capability of enhancing better service delivery and could aid better efficient internal control system that will bring about performance measurement in agencies. IPSAS accrual enhances creditability of government financial information and activities and will eventually result to confidence building and credibility. This finding was corroborated by Acho (2014) and Ofoegbu (2014).

\section{Methodology of research}

The survey research design was adopted for this study. Which was conducted in Yenagoa, Bayelsa State, Nigeria focusing on all the ministries, departments, parastatals as well as Niger Delta University, Amasoma, Federal University, Otuoke, Forensic Accountants, Charted accountants and staff of Office of the Accountant General of the Federation, Yenagoa Pay office, staff of the office of Auditor General of Bayelsa State and Local Government. All the persons considered to have a working knowledge of the usage of IPSAS and forensic accounting. The population size was one thousand four hundred (1400) and the sample size is three hundred (300), the Krejcie and Morgan (1970) sample size for research activities was used to determine the sample size (Table 1 ).

Table 1. Sample Size of the Study

\begin{tabular}{|l|c|}
\hline \multicolumn{1}{|c|}{ Details } & Population \\
\hline Accountants of Ministries, Departments and Agencies & 150 \\
\hline Forensic Accounting & 10 \\
\hline Budget Officers & 30 \\
\hline Lecturers of NDU and Federal University, Otuoke (accountancy department) & 30 \\
\hline Federal pay Office Yenagoa & 10 \\
\hline Charted Accountants & 46 \\
\hline Auditor General State/Local Government & 24 \\
\hline \multicolumn{1}{|c|}{ Total } & $\mathbf{3 0 0}$ \\
\hline
\end{tabular}

Source: Fieldwork (2019)

Data were collected through primary source by administration of questionnaires interview to the targeted respondents. The statistical tool employed in this study is the Chi-Square test. In testing the hypotheses, the SPSS ("Statistical Product and Service Solutions") version 22.0 and Excel 2010 version was used to analyse the data. The choice of the SPSS and Excel spreadsheet in analysing the data is based on the accuracy, ease and ability to accommodate voluminous data set. 


\section{Data Analysis and Interpretation of Results}

\subsection{Hypothesis One}

Chi-Square test on the effect of Accrual based IPSAS which provides more information to stakeholders than cash basis accounting system for decision making.

$\mathrm{H}_{1}$ : Accrual based IPSAS does not provide more information to stakeholders than cash basis accounting system for decision making

Table 2. Frequency for Hypothesis One

\begin{tabular}{|l|c|c|c|}
\hline \multicolumn{1}{|c|}{ Description } & Observed N & Expected N & Residual \\
\hline Strongly Agree & 207 & 58.0 & 149.0 \\
\hline Agree & 43 & 58.0 & -15.0 \\
\hline Strongly Disagree & 18 & 58.0 & -40.0 \\
\hline Disagree & 15 & 58.0 & -43.0 \\
\hline Neutral & 7 & 58.0 & -51.0 \\
\hline \multicolumn{1}{|c|}{ Total } & 290 & & \\
\hline
\end{tabular}

Source: Fieldwork (2019)

Table 3. Summary of Chi-Square Test Statistics

\begin{tabular}{|l|c|c|}
\hline & Accrual Accounting 1 & Frequency \\
\hline Chi-Square & 490.966 & 490.966 \\
\hline Df & 4 & 4 \\
\hline Asymp. Sig. & .000 & .000 \\
\hline
\end{tabular}

a. 0 cells $(.0 \%)$ have expected frequencies less than 5 . The minimum expected cell frequency is 58.0.

Table 3 showed that, the $X$ calculated $=490.966, X$ tabulated $=9.49$ degree of freedom (df). From the result shown above the calculated value of Chi-square is greater than the tabulated value. Hence, the null hypothesis was rejected and the alternate hypothesis was accepted.

\subsection{Hypothesis Two}

Chi-Square test on the increase of corruption in the public sector as a result of poor financial reporting and disclosure requirement

$\mathrm{H}_{2}$ : there is no significant relationship between Corruption in the public sector and poor financial reporting and disclosure requirement

Table 5 shows that Corruption in the public sector increases as a result of poor financial reporting and disclosure requirement since the chi-Square is $629.414, \mathrm{X}$ tabulated $=9.49$ degree of freedom (df). Hence, the null hypothesis was rejected.

Table 4. Frequency for Hypothesis Two

\begin{tabular}{|l|c|c|c|}
\hline \multicolumn{1}{|c|}{ Description } & Observed N & Expected N & Residual \\
\hline Strongly Agree & 228 & 58.0 & 170.0 \\
\hline Agree & 28 & 58.0 & -30.0 \\
\hline Strongly Disagree & 22 & 58.0 & -36.0 \\
\hline Disagree & 5 & 58.0 & -53.0 \\
\hline Neutral & 7 & 58.0 & -51.0 \\
\hline \multicolumn{1}{|c|}{ Total } & 290 & & \\
\hline
\end{tabular}

Source: Fieldwork (2019) 
Table 5. Summary of Chi-Square Test Statistics

\begin{tabular}{|l|c|c|}
\hline & Accrual Accounting2 & Frequency \\
\hline Chi-Square & 629.414 & 629.414 \\
\hline Df & 4 & 4 \\
\hline Asymp. Sig. & .000 & .000
\end{tabular}

a. 0 cells $(.0 \%)$ have expected frequencies less than 5 . The minimum expected cell frequency is 58.0 .

\subsection{Hypothesis Three}

Chi-Square test on the Accrual based IPSAS provision of more information to forensic accountants in executing their job

$H_{3}$ : Accrual based IPSAS does not provide more information to forensic accountants in executing their job

Table 6. Frequency for Hypothesis Three

\begin{tabular}{|l|c|c|c|}
\hline \multicolumn{1}{|c|}{ Description } & Observed N & Expected N & Residual \\
\hline Strongly Agree & 240 & 58.0 & 182.0 \\
\hline Agree & 20 & 58.0 & -38.0 \\
\hline Strongly Disagree & 12 & 58.0 & -46.0 \\
\hline Disagree & 11 & 58.0 & -47.0 \\
\hline Neutral & 7 & 58.0 & -51.0 \\
\hline Total & 290 & & \\
\hline
\end{tabular}

Source: Fieldwork (2019)

Table 7. Summary of Chi-Square Test Statistics

\begin{tabular}{|l|c|c|}
\hline & Accrual Accounting3 & Frequency \\
\hline Chi-Square & 715.414 & 715.414 \\
\hline Df & 4 & 4 \\
\hline Asymp. Sig. & .000 & .000 \\
\hline
\end{tabular}

a. 0 cells $(.0 \%)$ have expected frequencies less than 3 . The minimum expected cell frequency is 58.0.

On the other hand, Table 7 revealed that Accrual based IPSAS provide more information to forensic accountants in executing their job since the Chi-Square is 715.414 , the $X$ tabulated $=9.49$ degree of freedom (df). Hence, the null hypothesis was rejected.

\subsection{Hypothesis Four}

Chi-Square test on the Report generated by forensic accountants in building sound internal control mechanism in the public sector through IPSAS adoption.

$H_{4}$ : Report generated by forensic accountants will not help in building sound internal control mechanism in the public sector through IPSAS adoption

Table 8. Frequency for Hypothesis Four

\begin{tabular}{|l|c|c|c|}
\hline \multicolumn{1}{|c|}{ Description } & Observed N & Expected N & Residual \\
\hline Strongly Agree & 250 & 58.0 & 192.0 \\
\hline Agree & 22 & 58.0 & -36.0 \\
\hline Strongly Disagree & 6 & 58.0 & -52.0 \\
\hline Disagree & 9 & 58.0 & -49.0 \\
\hline Neutral & 3 & 58.0 & -55.0 \\
\hline \multicolumn{1}{|c|}{ Total } & 290 & & \\
\hline
\end{tabular}

Source: Fieldwork (2019) 
Table 9. Summary of Chi-Square Test Statistics

\begin{tabular}{|l|c|c|}
\hline & Accrual Accounting4 & Frequency \\
\hline Chi-Square & 798.103 & 798.103 \\
\hline Df & 4 & 4 \\
\hline Asymp. Sig. & .000 & .000 \\
\hline
\end{tabular}

a. 0 cells $(.0 \%)$ have expected frequencies less than 5 . The minimum expected cell frequency is 58.0.

Also, Table 9 shows that Report generated by forensic accountants helps in building sound internal control mechanism in the public sector through IPSAS adoption since the Chi-Square is 798.103, the $X$ tabulated $=9.49$ degree of freedom (df). Hence, the null hypothesis was rejected.

\section{Conclusions and recommendations}

This study examined the adoption of International Public Sector Accounting Standards (IPSAS) and its impact in reducing Corruption in the Nigerian Public Sector, results from the study indicated that: (a) accrual based IPSAS provide more information than cash basis accounting system for decision making. (b) That corruption is on the increase due to poor financial reporting and disclosure requirements. (c) That accrual basis of accounting IPSAS provides more information to forensic account experts in executing their job effectively. (d) Report generated by forensic accountants helps in building sound internal control architecture in the public sector through IPSAS adoption.

Based on the findings of this study, it is recommended that the three tiers of government should adopt IPSAS given its numerous benefits despites the challenges it may face in its implementation. Equally, the Financial Reporting Council of Nigeria/Federal Account Allocation Committee should enforce the constitutional mandatory requirement in publication of annual financial statements for stakeholders' usage as it is done to Annual budget appropriation. The mandatory and environmental peculiarities discretionary based disclosures requirements should be adequately addressed to meet varieties of stakeholder's demand. Finally, forensic accountants should be engaged by anti-corruption agencies in Nigeria to undertake adequate investigative corruption related cases in-order to provide for more control mechanism.

\section{References}

1. Acho, Y. (2014). The Challenges of Adopting International Public Sector Accounting Standard (IPSAS) By Nigeria. Journal of Social Sciences and Public Policy, 6 (2), 29-39.

2. Adedeji, D. B., Soyinka, K. A., Sunday, O. M. (2018). Corruption Control in the Public Sector and the Nigerian Accountant, International Journal of Academic Research in Accounting, Finance and Management Sciences, 8 (1): 91-103, http://dx.doi.org/10.6007/IJARAFMS/v8-i1/3920

3. Balboa, J., \& Medalla, E. M. (2006). Anti-Corruption and Governance: The Philippine Experience. APEC Study Centre Consortium Conference, Ho Chi Minh City, Viet Nam 23-24 May 2006, Asia-Pacific Economic Cooperation.

4. Barton, A. (2005). Professional Accounting Standards and the Public Sector-a Mismatch Abacus, 41(2), 138-158.

5. Carpenter, V. L., \& Feroz, E. H. (2001). Institutional theory and accounting rule choice: an analysis of four US state governments' decisions to adopt generally accepted accounting principles, Accounting, Organizations and Society, 26, 565-596.

6. Christensen, M., \& Skaerbaek, P. (2007) Framing and Overflowing of Public Sector Accountability Innovations. A Comparative Study of Reporting Practices. Accounting, Auditing\& Accountability Journal, 20(1):101-132.

7. Fabayo, J. A., Posu, S. M. A., \& Obisanya, A. A. (2011). "Corruption and the Investment Climate in Nigeria". Journal of Economic and Sustainable Development. 2(4).

8. Ijeoma, N. B., \& Oghoghomeh, T. (2014). Adoption of International Public Sector Accounting Standards in Nigeria: Expectations, Benefits and Challenges. Journal of Investment and Management, 3 (1): 21-29. Doi: 10.11648/j.jim.20140301.13.

9. Klitgaard, R. (1998) Forolberoamericanosobre el Combate a la Corrupción (1998 Jun. 15-16: Santa Cruz de la Sierra) CLAD; Agencia Española de Cooperación Internacional. 
10.Luder, K. G. (1992). 'A contingency model of governmental accounting innovations in the politicaladministrative environment', Research in Governmental and Nonprofit Accounting, 7: 99-127.

11.Nageri, K. I., Gunu, U., \& Abdul, F. A. (2013). Corruption and Economic Development: Evidence from Nigeria. Kuwait Chapter of Arabian Journal of Business and Management Review, 3 (2), 046-056.

12.Nongo, J. Y. (2014). IPSAS Issue for Public Finance Management Executive - IPSAS Outlook. E.Y com/IPSAS.

13.Ofoegbu, G. N. (2014). New Public Management and Accrual Accounting Basis for Transparency and Accountability in the Nigerian Public Sector. IOSR Journal of Business and Management (IOSR-JBM) 6 (7), 104-113.

14.Okeke, L. O. (2012). Bribery \& corruption trends in Nigeria: Ernst \& Young West Africa 12th Global Fraud Survey Launch Event 22 October 2012, Lagos.

15. Osunyikanmi, P. O. (2007). "Development Implication of Nigeria's Economic Crisis". Journal of Development Perspective. 2(1), 34-59.

16.Oulasvirta, L. (2008). How should pension benefit liabilities and social policy cash transfer liabilities be presented in the government financial statements: Current presentation mode or the mode of international IPSAS standards? The Finnish Journal of Business Economics, 2/2008.

17.Ryan, C. (1998). The Introduction of Accrual Reporting Policy in the Australian Public Sector: An Agenda Setting Explanation, Accounting, Auditing and Accountability Journal, 11(5), 518-539

18.Khan, M. A. (2006). Role of audit in fighting corruption, Paper for UN Ad Hoc Group Meeting on "Ethics, Integrity, and Accountability in the Public Sector: Re-building Public Trust in Government through the Implementation of the UN Convention against Corruption", St. Petersburg, Russia. Available at: http://unpan1.un.org/intradoc/groups/public/documen ts/UN/UNPAN025122.pdf Accessed 04.11.19. 